\title{
Acute and Sub-acute Toxicity Studies of Ethanol and Chloroform Extracts of Solanum giganteum Jacq. Leaves
}

\author{
Vikas Suresh Shende ${ }^{1,2, *}$, Jagdish Labhubhai Kakadiya ${ }^{1}$ \\ 'Department of Pharmacology, Parul Institute of Pharmacy and Research, Parul University, Vadodara, Gujarat, INDIA. \\ 2Department of Pharmacology, Satara College of Pharmacy, Satara, Maharashtra, INDIA.
}

\begin{abstract}
Objectives: To investigate the acute and subacute oral toxicity of ethanol and chloroform extracts Solanum giganteum Jacq (SG) leaves in a rodent for evaluating its safety profile. Methods: Solanum giganteum Jacq leaves extract for the acute oral toxicity ( 300 to $5000 \mathrm{mg} / \mathrm{kg}$ ) and subacute oral toxicity SG-Chloro (SGC 50, 200, $500 \mathrm{mg} / \mathrm{kg}$ ) and SG-Alcohol (SGA 100 $500,1000 \mathrm{mg} / \mathrm{kg}$ ) studies were administered orally according to the guidelines 423 and 407 of OECD, respectively. Results: In the acute oral toxicity study, doses are administered by $300 \mathrm{mg} / \mathrm{kg}$ to $5000 \mathrm{mg} / \mathrm{kg}$. SGA does not show toxicity up to $5000 \mathrm{mg} / \mathrm{kg}$, SGC shows toxicity at a dose of $2000 \mathrm{mg} / \mathrm{kg}$. In the subacute toxicity study, the daily oral treatment with extracts of SGA $100,500,1000 \mathrm{mg} / \mathrm{kg}, \mathrm{SGC} 50,200,500 \mathrm{mg} / \mathrm{kg}$ of extracts for 28 days did not produce any death or hazard. Likewise, SGA 100, 500, $1000 \mathrm{mg} / \mathrm{kg}$, SGC 50, $200 \mathrm{mg} / \mathrm{kg}$ of Solanum giganteum Jacq no significant changes were recorded in food intake, body weight gain, the biochemical and haematological parameter of control and treated rats. SGC $500 \mathrm{mg} /$ $\mathrm{kg}$ of significant changes were recorded in food intake and body weight gains were decreased compared to the control group. SGC $500 \mathrm{mg} / \mathrm{kg}$ of
\end{abstract}

extract treaded group saw mild liver pathological findings characterized by abnormal hepatic configuration was observed with treated animals. Conclusion: The acute and subacute toxicity study Solanum giganteum Jacq alcohol extract is considered relatively safe on acute and subacute oral exposure. Solanum giganteum Jacq chloroform extract shows acute toxicity at dose $2000 \mathrm{mg} / \mathrm{kg}$ and in subacute toxicity study, higher dose $500 \mathrm{mg} / \mathrm{kg}$.

Key words: Solanum giganteum, Acute toxicity, Aubacute toxicity, OECD, SG-Chloro, SG-alcohol.

Correspondence

Mr. Vikas S Shende,

Satara College of Pharmacy, New Additional MIDC, Behind Spicer India Ltd, Degaon, Satara-415 004, Maharashtra, INDIA.

Email id: vikas_shende2003@yahoo.co.in

DOI: 10.5530/jyp.2022.14.12

\section{INTRODUCTION}

In recent years, there has been an indication of the increasing popularity of complementary and alternative medicine approaches to health in India. Even with rapid growth, there is inadequate evidence about the efficiency and toxicity of alternative medicine. Much more needs to be done to increase the evidence base for herbals, botanicals, and dietary supplements. Since ancient times, plants have been a basic source of drugs, but scientific medicine tends to no attention to the importance of herbal medicine. ${ }^{1}$

Approximately any substance can be harmful at a few doses but, at the same time, can be without harmful effects at some lower dose. Between these two limits, there is a variety of possible effects, from delicate long-term chronic toxicity to instant lethality. The large range of toxic chemicals formed by plants (phytotoxins), commonly referred to as secondary plant compounds, is often held to have developed as defence mechanisms against animals, mainly insects and mammals. Many toxic chemicals are constituents of plants that form part of the human diet. ${ }^{2}$

The many varieties in the plant of the genus Solanaceae. There may be up to around 1,500 species worldwide. With a few 800 conventional specific and infraspecific taxa of the more than 4,000 described, the genus Solanum contains more species than any other genus in the Solanaceae family and it is one of the majors between the angiosperms.

Solanum giganteum (Family: Solanaceae) Much-branched shrub or small tree up to $6 \mathrm{~m}$ high. Branchlets with white, woolly hairs and stout, straight prickles up to $5 \mathrm{~mm}$ long. Leaves elliptic, margin entire, large, up to 250 x $90 \mathrm{~mm}$, softly textured, dark green, glabrescent. Flowers in many-flowered, branched, dense, terminal corymbs faintly scented; corolla white, mauve to blue or purple, $15 \mathrm{~mm}$ in diameter, anthers yellow. Distributed in almost all parts of the world and abundantly found in Tropical Africa, India (Maharashtra; Gujarat; Punjab and Rajasthan). In India, it is widely distributed. Traditionally it is used treat as an antiinflammatory, antibacterial, antifungal, and much more. ${ }^{3-8}$

Hence, in the existing work, Acute and subacute oral toxicity estimation of ethanol and chloroform extracts of Solanum giganteum Jacq leave. No clinical proof or studies for the oral acute and sub-acute oral toxicity investigation for this plant are available in the literature. Therefore, acute and sub-acute oral toxicity studies were carried out by the OECD guidelines to verify and set up the safety for its use in clinical practice. The purpose of this study was to estimate the safety of Solanum giganteum in animals' models.

\section{MATERIALS AND METHODS}

\section{Plant material}

The plant Solanum giganteum Jacq was collected in November 2020, from the area of Satara Maharashtra, India, the specimen was authenticated by comparing it with the voucher specimen deposited in the Department of Botany by Y.C. Institute of Science, Satara, Maharashtra, India

\section{Preparation of extract}

Freshly collected leaves of the plant Solanum giganteum Jacq. were dried at room temperature for three weeks. The dried plant material was made a coarse powder and weighed the quantity of the powder $(500 \mathrm{~g})$ 
was subjected to hot extraction in a soxhlet apparatus using petroleum ether, chloroform, ethanol, at a temperature range of $40-80^{\circ} \mathrm{C}$. The marc was completely dried and weighed, before and after every extraction. At room temperature, the extract was concentrated by evaporation of the solvent. ${ }^{9,10}$

\section{Animals}

Adult healthy albino mice weighing 25-30 g and Wister rat 150- $200 \mathrm{~g}$ were used and kept in the animal house of the Department of Pharmacology, Satara College of Pharmacy, Satara. The animals were kept in plastic cages $(34 \times 47 \times 18 \mathrm{~cm} 3)$ at the animal house, in an airconditioned environment with $\mathrm{T}$ in each cage and maintained at room temperature of $(25 \pm 2)^{\circ} \mathrm{C}$ with relative humidity $(60 \% \pm 10 \%)$ under $12 \mathrm{hr}$ night and light cycle. The experimental protocol was permitted by the Institutional Animal Ethics Committee of Satara College of Pharmacy, Satara and was carried out according to the CPCSEA guidelines for laboratory animal facilities. Protocol sanction number Protocol No.: SCOP/IAEC/102/2020 (CPCSEA registration number1314/PO/Re/S/2009/CPCSEA)

\section{Acute toxicity studies}

The acute oral toxicity study of extracts of SG-Chloro and SG-Alcohol of Solanum giganteum Jacq. was estimated according to the OECD guideline 423 on mice $(20-30 \mathrm{~g})$, where the maximum test dose of $5000 \mathrm{mg} / \mathrm{kg}$ was used.

All the animals were set aside at overnight fasting before every experiment with free excess to water. The animals were separated into four groups, each comprising 3 animals. The $1^{\text {st }}$ group, $2^{\text {nd }}, 3^{\text {rd }}$ and $4^{\text {th }}$ were considered as tested groups administrated orally extracts (dissolved in normal saline) extract at a dose of $300 \mathrm{mg} / \mathrm{kg}, 1000 \mathrm{mg} / \mathrm{kg}, 2000 \mathrm{mg} / \mathrm{kg}$ and $5000 \mathrm{mg} / \mathrm{kg}$. Before the dose was received, the bodyweight of each animal was estimated, and the dose was measured according to the body weight.

The animals were observed for any toxic signs and symptoms for the first $4 \mathrm{~h}$ after the treatment period. Additionally, animals were examined for 14 days for any toxic effect. Behavioural changes and other factors such as body weight, urination, food intake, water intake, respiration, convulsion, tremor, temperature constipation, changes in eye and skin colours, etc. ${ }^{11,12}$

\section{Subacute toxicity studies}

The subacute oral toxicity study of extracts of SG-Chloro, SG-Alcohol of Solanum giganteum Jacq was estimated according to OECD guideline 407 on Wister rats (150-200 g).

The Wistar rats were randomly allocated to three groups by sex $(n=6$, $\mathrm{M}=3, \mathrm{~F}=3$ ). The first group was provided distilled water orally (control group). Groups 2 to 7 were orally treated with (low, medium, high Doses) extracts of SG-Chloro $(50,200,500 \mathrm{mg} / \mathrm{kg})$ and SG-Alcohol $(100,500,1000 \mathrm{mg} / \mathrm{kg})$ of Solanum giganteum Jacq respectively, for 28 consecutive days. All animals were supplied with feed and water ad libitum throughout the testing periods. The clinical sign was monitored daily for physiological and behavioural changes. Toxic symptoms such as toxicity and death were observed for signs of abnormalities. Bodyweight changes were recorded weekly and food consumption and water intake were observed daily. At the finish of treatment, the animals were fasted overnight but permitted administered to water ad libitum. They were then anaesthetized and blood samples were collected by retro-orbital puncture using capillary tubes with or without the anticoagulant. ${ }^{13}$

\section{Haematological Analysis}

The blood samples collected with the anticoagulant were used immediately for the determination of haematological parameters such as red blood corpuscles (RBC) count, white blood corpuscles (WBC) count, haemoglobin $(\mathrm{Hb})$ and platelet count were performed using a blood cell counter. ${ }^{14}$

\section{Biochemical analysis}

The blood samples collected without the anticoagulant was centrifuged at $4,000 \mathrm{rpm}$ for $10 \mathrm{~min}$ to separate the serum. The serum was investigated for biochemical constraints such as glucose, urea, aspartate aminotransferase (AST), alanine aminotransferase (ALT), alkaline phosphatase (ALP) and total protein employing standard diagnostic kits. ${ }^{15}$

\section{Necropsy}

At the finish of the protocol, the animals were anaesthetized and necropsy was performed on randomly preferred animals of each group per sex to investigate the macroscopic external features of vital organs such as the liver. The organ is cautiously detached and weighed. Organ weights were recorded in comparative terms (gram per $100 \mathrm{~g}$ of body weight). The collected organs were fixed in $10 \%$ buffered formalin and fixed in paraffin. Histology sections ( $5 \mu \mathrm{m}$ thick) were stained with hematoxylin and observed under a light microscope

\section{Statistical analysis}

Statistical analysis was done by using one way ANOVA followed by Dunnett's Comparison Test for comparison between different groups using Graph pad prism-5 software. A $p<0.05$ was considered statistically significant

\section{RESULTS}

\section{Acute toxicity studies}

Acute toxicity study of extracts of SG-Alcohol, SG-Chloro of Solanum giganteum Jacq.

Oral acute toxicity was estimated according to the guidelines of the OECD. Doses are administered by the $300 \mathrm{mg} / \mathrm{kg}, 1000 \mathrm{mg} / \mathrm{kg}, 2000 \mathrm{mg} / \mathrm{kg}$ and $5000 \mathrm{mg} / \mathrm{kg}$ (OECD guideline no. 423). SG-Alcohol does not show toxicity up to $5000 \mathrm{mg} / \mathrm{kg}$, SG-Chloro shows toxicity at a dose of $2000 \mathrm{mg} / \mathrm{kg}$.

\section{Subacute toxicity studies Effect of extracts of SG-alcohol and SG-chloro of solanum giganteum jacq on general signs and bodyweight}

The daily oral treatment with extracts of SG-Alcohol (SGA 100, 500, $1000 \mathrm{mg} / \mathrm{kg}$ ), SG-Chloroform (SGC 50, 200, $500 \mathrm{mg} / \mathrm{kg}$ ) of Solanum giganteum Jacq extracts for 28 days did not produce any death or hazardous sign such as piloerection, alteration in the locomotor activity and other physiological activities as compared to the control animals. Likewise, SGA 100, 500, $1000 \mathrm{mg} / \mathrm{kg}$, SGC 50, $200 \mathrm{mg} / \mathrm{kg}$ of Solanum giganteum Jacq no significant changes were recorded in food intake and body weight gain of control and treated rats (Table 1 and 2). SGC 500 $\mathrm{mg} / \mathrm{kg}$ of Solanum giganteum significant changes were recorded in food intake and body weight gains are decrease compared to control group.

\section{Haematological and biochemical parameters}

The effects of subacute administration of SG-Alcohol (SGA 100, $500,1000 \mathrm{mg} / \mathrm{kg}$ ) and SG-Chloroform (SGC 50, 200, $500 \mathrm{mg} / \mathrm{kg}$ ) of Solanum giganteum Jacq extracts on haematological and biochemical parameters are presented in Tables 3 and 4 . Most haematology measures 
Shende and Kakadiya.: Acute and Subacute oral toxicity of Solanum giganteum Jacq. leaves.

Table 1: Effect of Solanum giganteum extracts on food intake.

\begin{tabular}{|c|c|c|c|c|c|c|c|}
\hline \multicolumn{8}{|c|}{ Groups } \\
\hline \multirow[b]{2}{*}{ Days } & \multirow[b]{2}{*}{ Control } & \multicolumn{3}{|c|}{$\mathrm{SGC} \mathrm{mg} / \mathrm{kg}$} & \multicolumn{3}{|c|}{$\mathrm{SGA} \mathrm{mg} / \mathrm{kg}$} \\
\hline & & 50 & 200 & 500 & 100 & 500 & 1000 \\
\hline \multirow[t]{2}{*}{7} & 30 & 29 & 28 & 27 & 27 & 26 & 28 \\
\hline & \pm 0.25 & \pm 0.28 & \pm 0.14 & \pm 0.12 & $\begin{array}{c} \pm \\
0.26\end{array}$ & \pm 0.22 & \pm 0.26 \\
\hline \multirow[t]{2}{*}{14} & 32 & 31 & 27 & 29 & 30 & 28 & 31 \\
\hline & \pm 0.24 & \pm 0.32 & \pm 0.42 & \pm 0.22 & \pm 0.35 & \pm 0.14 & \pm 0.32 \\
\hline \multirow{2}{*}{28} & 33 & 34 & 32 & 27 & 33 & 34 & 33 \\
\hline & \pm 0.44 & \pm 0.14 & \pm 0.45 & $\pm 0.42^{*}$ & $\begin{array}{c} \pm \\
0.48\end{array}$ & \pm 0.35 & \pm 0.54 \\
\hline
\end{tabular}

Effect of SGC and SGA extracts on food intake in rats. Data are mean SEM values ( $n=6$ in each group). Data were analyzed by one way ANOVA followed by Dunnett test Comparisons test. ${ }^{*} P<0.05$ compared with normal control.

Table 2: Effect of Solanum giganteum Extracts on Bodyweight (gm).

\begin{tabular}{cccccccc}
\hline & \multicolumn{9}{c}{ Groups } \\
\cline { 3 - 8 } Days & Control & 50 & 200 & 500 & 100 & 500 & 1000 \\
\cline { 2 - 8 } & 164.33 & 161.3 & 158.3 & 162.16 & 160.1 & 156.3 & 158.17 \\
& \pm 3.33 & \pm 1.73 & \pm 1.84 & \pm 1.2 & \pm 1.3 & \pm 1.21 & \pm 1.3 \\
\multirow{2}{*}{14} & 168.43 & 166.3 & 162.3 & 163.7 & 167.4 & 160.4 & 162.1 \\
& \pm 2.38 & \pm 1.93 & \pm 2.43 & \pm 0.6 & \pm 2.44 & \pm 2.11 & \pm 2.44 \\
28 & 173.23 & 171.6 & 168.6 & 154.1 & 170.5 & 170.3 & 168.1 \\
& \pm 1.39 & \pm 1.15 & \pm 0.15 & $\pm 0.6^{* *}$ & \pm 1.18 & \pm 2.41 & \pm 1.18 \\
\hline
\end{tabular}

Effect of SGC and SGA extracts on Body weight in rats. Data are mean SEM values ( $n=6$ in each group). Data were analyzed by one way ANOVA followed by Dunnett test Comparisons test. ${ }^{*} P<0.01$ compared with normal control.

Table 3: Effect of Solanum giganteum extracts on haematological parameters in a subacute oral toxicity study.

\begin{tabular}{|c|c|c|c|c|c|c|c|}
\hline \multicolumn{8}{|c|}{ Groups } \\
\hline \multirow[b]{2}{*}{ Parameter } & \multirow[b]{2}{*}{ Control } & \multicolumn{3}{|c|}{$\mathrm{SGC} \mathrm{mg} / \mathrm{kg}$} & \multicolumn{3}{|c|}{ SGA mg/kg } \\
\hline & & 50 & 200 & 500 & 100 & 500 & 1000 \\
\hline $\mathrm{Hb}$ & 12.5 & 12.8 & 12.66 & 11.6 & $12.4 \pm$ & 12.9 & 12.1 \\
\hline$(\mathrm{g} / \mathrm{dL})$ & \pm 1.2 & \pm 3.8 & \pm 3.8 & \pm 1.28 & 0.95 & \pm 1.65 & \pm 1.62 \\
\hline $\mathrm{RBC}$ & 6.5 & 6.3 & 6.87 & 5.9 & 6.4 & 6.7 & 7.01 \\
\hline$\left(10^{6} / \mathrm{mm} 3\right)$ & \pm 2.3 & \pm 3.6 & \pm 2.8 & \pm 2.3 & \pm 1.3 & \pm 1.3 & \pm 2.0 \\
\hline WBC & 7.6 & 7.6 & 7.9 & 9.92 & 7.3 & 7.1 & 7.4 \\
\hline$\left(10^{3} / \mathrm{mm}^{3}\right)$ & \pm 0.32 & \pm 1.3 & \pm 2.3 & $\pm 0.7^{*}$ & \pm 1.6 & \pm 1.6 & \pm 1.85 \\
\hline Platelets & 6.74 & 6.32 & 6.52 & 6.15 & 6.44 & 6.84 & 6.26 \\
\hline $10^{5} / \mathrm{mm}^{3}$ & \pm 1.24 & \pm 2.2 & \pm 3.2 & \pm 1.73 & \pm 1.54 & \pm 2.84 & \pm 1.41 \\
\hline
\end{tabular}

Effect of SGC and SGA extracts on the haematological parameter in rats. Data are mean SEM values ( $n=6$ in each group). Data were analyzed by one way ANOVA followed by Dunnett test Comparisons test. ${ }^{\star} P<0.05$ compared with normal control.

(haemoglobin, total red blood cells, total white blood cells, and platelet count) in treated rats were not significantly different from the controls group, except marginal variations in certain parameters of SGA 100, $500,1000 \mathrm{mg} / \mathrm{kg}$, SGC 50, $200 \mathrm{mg} / \mathrm{kg}$ of Solanum giganteum Jacq treated group. SG-Chloroform (SGC $500 \mathrm{mg} / \mathrm{kg}))$ there was significant $(P<0.05)$
Table 4: Effect of Solanum giganteum extracts on biochemical parameters in subacute oral toxicity study.

\begin{tabular}{cccccccc}
\hline & \multicolumn{9}{c}{ Groups } \\
\hline & & \multicolumn{3}{c}{ SGC mg/kg } & \multicolumn{3}{c}{ SGA mg/kg } \\
\cline { 3 - 8 } Parameter & Control & 50 & 200 & 500 & 100 & 500 & 1000 \\
\hline ALT (IU/L) & 36.6 & 39.14 & 41.24 & 53.83 & 37.5 & 38.5 & 39.8 \\
& \pm 3.3 & \pm 1.2 & \pm 1.8 & $\pm 1.5^{* *}$ & \pm 3.1 & \pm 3.1 & \pm 2.7 \\
AST (IU/L) & 89.97 & 93.4 & 94.4 & 108.9 & 88.40 & 91.80 & 94.12 \\
& \pm 5.15 & \pm 2.6 & \pm 2.8 & $\pm 4.6^{* *}$ & \pm 3.17 & \pm 7.77 & \pm 6.46 \\
ALP (IU/L) & 101.4 & 105.5 & 106.8 & 115.5 & 103.8 & 100.5 & 106.4 \\
& \pm 4.2 & \pm 2.4 & \pm 3.2 & $\pm 2.1^{* *}$ & \pm 4.6 & \pm 3.1 & \pm 2.8 \\
Total & 6.9 & 6.6 & 7.6 & 9.4 & 6.7 & 6.4 & 6.8 \\
protein & \pm 1.3 & \pm 2.4 & \pm 4.3 & $\pm 2.2^{* *}$ & \pm 4.7 & \pm 1.7 & \pm 2.4 \\
(gm/dL) & & & & & & & \\
\hline
\end{tabular}

Effect of SGC and SGA extracts on Biochemical parameters in rats. Data are mean SEM values ( $n=6$ in each group). Data were analyzed by one way ANOVA followed by Dunnett test Comparisons test. ${ }^{* *} P<0.01$ compared with normal control.

initiation in WBC (24\%) counts in the treated animals compared to that of the control group.

No statistically significant differences in liver function parameters (ALT, AST, and alkaline phosphatase and Total protein) were noted except for marginal variations seen in SGA 100, 500, $1000 \mathrm{mg} / \mathrm{kg}$ and SGC 50, $200 \mathrm{mg} / \mathrm{kg}$ of Solanum giganteum Jacq extracts treated group.

SGC $500 \mathrm{mg} / \mathrm{kg}$ of Solanum giganteum Jacq and extracts treaded group significant $(P<0.05)$ induction (ALT, AST, and alkaline phosphatase and Total protein).

\section{Histopathological studies}

In the subacute oral toxicity study, microscopic analysis of the histological sections of the liver (Figure 1) did not show evidence of any histological abnormalities such as inflammation, necrosis, degeneration, cellular infiltration, vascular changes and haemorrhage or cellular abnormalities in both normal and treated animals of SG-Alcohol (SGA 100, 500, $1000 \mathrm{mg} / \mathrm{kg}$ ), and SG-Chloroform (SGC 50, $200 \mathrm{mg} / \mathrm{kg}$ ) of Solanum giganteum Jacq extracts.

SGC $500 \mathrm{mg} / \mathrm{kg}$ of Solanum giganteum Jacq extract treaded group seen mild liver pathological findings characterized by abnormal hepatic configuration were observed with treated animals.

\section{DISCUSSION}

An oral acute toxicity test estimated the adverse consequences that occur within a short time after administration of a solo dose of a test substance. This testing was carried out primarily in rodents and regularly done early in the discovery of a new chemical or product to supply information on its probable toxicity.

For acute oral toxicity study, extracts of SG-Alcohol and SG-Chloro of Solanum giganteum Jacq were given to mice at a dose of $300 \mathrm{mg} / \mathrm{kg}$ to $5000 \mathrm{mg} / \mathrm{kg}$. SG-Alcohol groups did not show any signs of toxicity at all doses employed. No death was observed in the treated groups, i.e., at $300 \mathrm{mg} / \mathrm{kg}$ to $5000 \mathrm{mg} / \mathrm{kg}$ during the study period. Therefore, the $\mathrm{LD}_{50}$ of the extract could be more than $5000 \mathrm{mg} / \mathrm{kg}$. The SG-Alcohol extract may, therefore, be considered comparatively safe on acute exposure.

SG-Chloro of Solanum giganteum Jacq extract did not produce any signs of toxicity at a dose of $300 \mathrm{mg} / \mathrm{kg}$ to $1500 \mathrm{mg} / \mathrm{kg}$ and a dose of $2000 \mathrm{mg} / \mathrm{kg}$ 

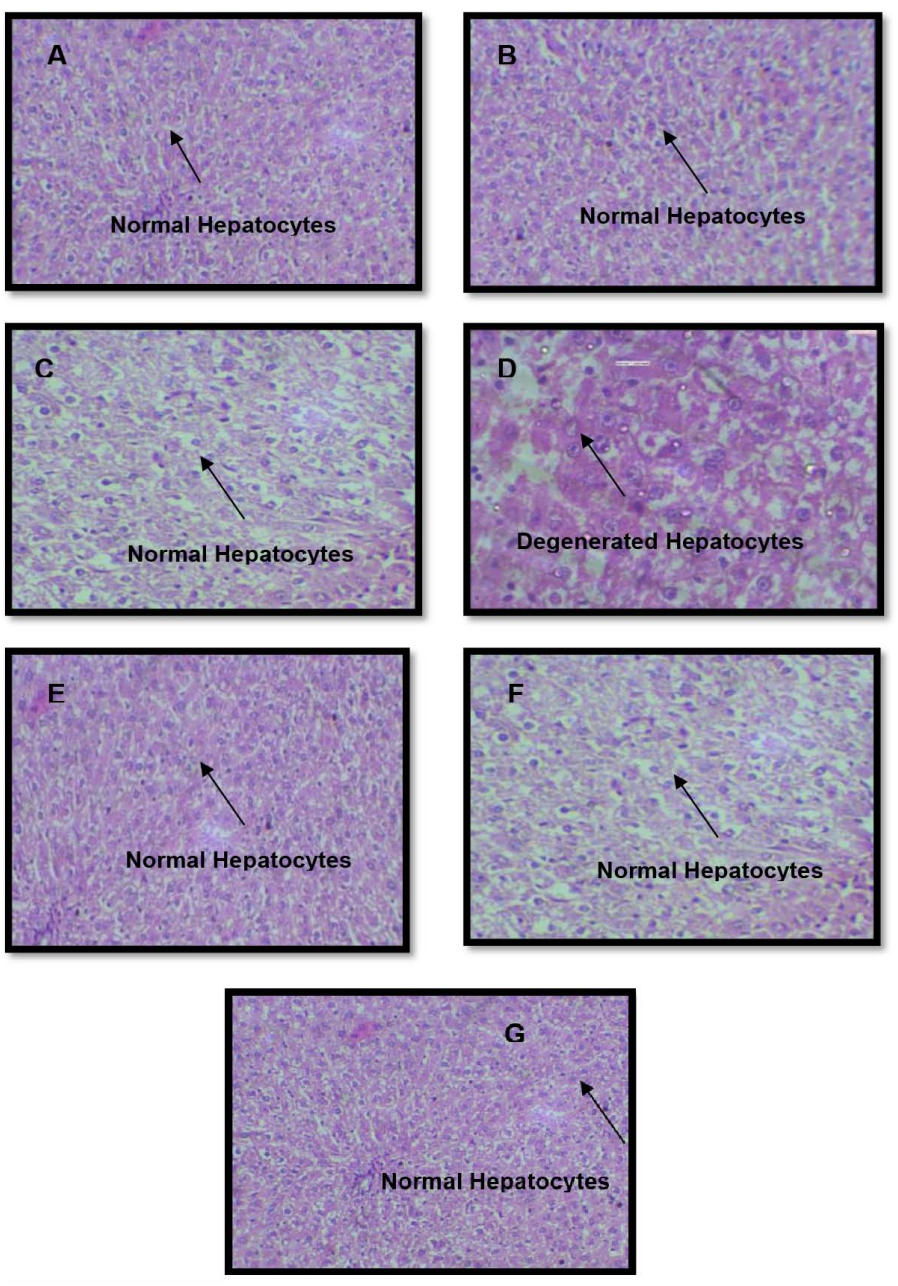

A. Normal B. SGC $50 \mathrm{mg} / \mathrm{kg}$ C. SGC $200 \mathrm{mg} / \mathrm{kg}$ D. SGC $500 \mathrm{mg} / \mathrm{kg}$ E. SGA $100 \mathrm{mg} / \mathrm{kg}$ F. SGA $500 \mathrm{mg} / \mathrm{kg}$

Figure 1: Photomicrographs of rat liver tissue section under low power.

shows toxicity 3 out of 2 animals deaths. Therefore SG-Chloro $\mathrm{LD}_{50}$ was found at a dose of $2000 \mathrm{mg} / \mathrm{kg}$.

An acute oral toxicity study gives a guideline to decide the doses for subacute toxic study (low, medium and high) which may be a more clinically applicable group after 28 days of daily treatment. On basis of acute toxicity study for subacute administration of SG-Alcohol (SGA $100,500,1000 \mathrm{mg} / \mathrm{kg}$ ) and SG-Chloroform (SGC 50, 200, $500 \mathrm{mg} / \mathrm{kg}$ ) of Solanum giganteum Jacq.

In the hematopoietic system, individual one of the most susceptible targets of toxic chemicals is a significant index of the physiological and pathological category of humans and animals. In this study, the test groups of SGA 100, 500, $1000 \mathrm{mg} / \mathrm{kg}$ and SGC 50, $200 \mathrm{mg} / \mathrm{kg}$ of Solanum giganteum Jacq treaded group did not illustrate any significant variation in the haematological parameters except SGC $500 \mathrm{mg} / \mathrm{kg}$ there was significant $(P<0.05)$ initiation in WBC $(24 \%)$ counts in the treated animals compared to that of the control group.

The liver has an essential role in the metabolism of drugs or plant products. Exogenous chemicals and their metabolites might affect toxicity or cell damage on this organ. In the current histopathological examination of the liver, treated animals of SGA 100, 500 and $1000 \mathrm{mg} / \mathrm{kg}$ and SGC 50 and $200 \mathrm{mg} / \mathrm{kg}$ of Solanum giganteum Jacq. Showed no change in the microscopic structure of the liver. The common architecture of the liver, the appearance of the hepatocytes, the hepatic sinusoids, portal triads, and central veins are normal as compared with controls. The result was also accompanied by the non-adverse effects of the extracts in any of the biochemical markers (such as ALT, AST and alkaline phosphatase and Total protein), which showed statistically insignificant changes compared with a control group. SGC $500 \mathrm{mg} / \mathrm{kg}$ of Solanum giganteum Jacq extract treaded group seen mild liver pathological findings characterized by abnormal hepatic configuration were observed with treated animals. SGC $500 \mathrm{mg} / \mathrm{kg}$ of extract treaded group significant $(P<0.05)$ induction (ALT, AST, and alkaline phosphatase and Total protein) found in the liver and this dynamic in the respected study.

\section{CONCLUSION}

The present result from the acute and subacute oral toxicity study Solanum giganteum Jacq. SG-Alcohol extract are considered comparatively safe on acute and subacute oral exposure. The SG-chloroform extract shows acute oral toxicity at dose $2000 \mathrm{mg} / \mathrm{kg}$ and in subacute toxicity study, higher dose $500 \mathrm{mg} / \mathrm{kg}$ shows by abnormal hepatic configuration were observed with treated animals.

\section{ACKNOWLEDGEMENT}

The authors are thankful for the financial support provided by Shivaji University, Kolhapur, Maharashtra, India.

\section{CONFLICT OF INTEREST}

The authors declare that there is no conflict of interest.

\section{ABBREVIATIONS}

SG: Solanum giganteum Jacq.; SGA: Solanum giganteum alcohol extract; SGC: Solanum giganteum chloroform extract; WBC: White blood cells; ALT: Alanine transaminase; AST: Aspartate aminotransferase; ALP: Alkaline phosphatase.

\section{REFERENCES}

1. Das N, Goshwami D, Hasan MS, Raihan SZ. Evaluation of acute and subacute toxicity induced by methanol extract of Terminalia citrina leaves in Sprague Dawley rats. J Acute Dis. 2015;4(4):316-21. doi: 10.1016/j.joad.2015.05.001.

2. Abbas MY, Ejiofor JI, Yakubu MI. Acute and chronic toxicity profiles of the methanol leaf extract of Acacia ataxacantha D.C (Leguminosae) in Wistar rats Bull Fac Pharm Cairo Univ. 2018;56(2):185-9. doi: 10.1016/j.bfopcu.2018.09.001.

3. Kumar GP, Khanum F. Neuroprotective potential of phytochemicals. Pharmacogn Rev. 2012;6(12):81-90. doi: 10.4103/0973-7847.99898, PMID 23055633.

4. Babawale OP, Taiye FR, Adetunji OS. Ethnobotanical survey of plants used as memory enhancer in three states of southwestern Nigeria. J App Pharm Sci. 2016;6(09):209-14. doi: 10.7324/JAPS.2016.60931.

5. Jayakumar K, Murugan K. Solanum alkaloids and their pharmaceutical roles: A review. J Anal Pharm Res. 2016; 3(6);00075.

6. Patel K, Singh RB, Patel DK. Medicinal significance, pharmacological activities, and analytical aspects of solasodine: A concise report of current scientific literature. J Acute Dis. 2013;2(2):92-8. doi: 10.1016/S2221-6189(13)60106-7.

7. Manasa S, Raju AB. Antiamnesic activity of Solanum melongena L. extract. Postepy Fitoterapii. 2014;1:3-9.

8. Sharma T, Airao V, Panara N, Vaishnav D, Ranpariya V, Sheth N, et al. Solasodine protects rat brain against ischemia/reperfusion injury through its antioxidant activity. Eur J Pharmacol. 2014;725:40-6. doi: 10.1016/j.ejphar.2014.01.005, PMID 24444441.

9. Shende VS, Jadhav SD, Aloorkar NH, Kulkarni AS, Suryavanshi SV. Pharmacognostic and phytochemical evaluation of Strobilanthes sessilis nees. Leaves. Int J Pharmacogn. 2015;2:310-4

10. Karthiyayini R. Pharmacognostic and preliminary phytochemical studies of Celosia argentea, L. Leaf. Int J Pharmacogn Phytochem Res. 2015;7(02):237-9

11. Prabu PC, Panchapakesan S, Raj CD. Acute and sub-acute oral toxicity assessment of the hydroalcoholic extract of Withania somnifera roots in Wistar rats. Phytother Res. 2013;27(8):1169-78. doi: 10.1002/ptr.4854, PMID 22996349. 
12. OECD. Guidelines for the testing of new chemicals revised draft guideline; acute oral toxicity,2001https://ntp. Available from: http://niehs.nih.gov/iccvam/ suppdocs/feddocs/oecd/oecd_gl423.pdf [cited 20/1/2022].

13. Bothiraja C, Pawar AP, Shende VS, Joshi PP. Acute and subacute toxicity study of andrographolide bioactive in rodents: Evidence for the medicinal use as an alternative medicine. Comp Clin Pathol. 2013;22(6):1123-8. doi: 10.1007/ s00580-012-1539-x.

14. Freitas de Lima F, Traesel GK, Menegati SE, Santos AC, Souza RI, De Oliveira VS, et al. Acute and subacute oral toxicity assessment of the oil extracted from Attalea phalerata Mart ex Spreng. pulp fruit in rats. Food Res Int. 2017;91:11-7. doi: 10.1016/j.foodres.2016.11.019, PMID 28290314.
15. Brígido HPC, Varela ELP, Gomes ARQ, Bastos MLC, De Oliveira Feitosa A, Do Rosário Marinho AM, et al. Evaluation of acute and subacute toxicity of ethanolic extract and fraction of alkaloids from bark of Aspidosperma nitidum in mice [sci rep:18283]. Sci Rep. 2021;11(1):18283. doi: 10.1038/s41598-02197637-1, PMID 34521944.

16. Silva JC, Diniz TC, Lavor ÉM, Silva MG, Lima-Saraiva SR, Oliveira-Junior RG, et al. Acute and subacute toxicological studies of Annona vepretorum in experimental animals. Planta Med Int Open. 2019;6(1):e15-22. doi: 10.1055/a0833-8785.

Article History: Received: 07-12-2021; Revised: 10-01-2022; Accepted: 29-01-2022

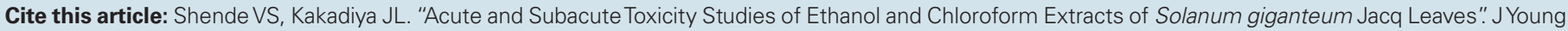
Pharm. 2022;14(1):62-6. 